\title{
Optimalisasi IGTV Sebagai Sarana Promosi Produk Bagi Perempuan Bekerja Korban Pemutusan Hubungan Kerja Pada Masa Pandemi Covid-19
}

\author{
Indah Handaruwati, Adhita Maharani Dewi \\ Fakultas Ekonomi Universitas Kristen Surakarta \\ Jln.R. Wolter Monginsidi 36-38 Surakarta \\ indahhandaruwati80@gmail.com
}

\begin{abstract}
This research is entitled Optimizing IGTV as a Product Promotion Facility for Women Victims of Termination of Employment during the Covid 19 Pandemic. products with a wider range. There are things that are the focus of discussion, namely the development of social media Instagram and the features in it, the role of social media Instagram as a means of product promotion, motivation for online businesses of women affected by Covid 19, the benefits of entrepreneurship for women who are laid off to improve the economy in the current pandemic era, the optimization of IGTV as a product promotion strategy is the obstacle in optimizing IGTV. The method used in this research is descriptive qualitative, where data collection is carried out through the method of interviewing 15 mothers who initially worked but because of the pandemic they became victims of termination of employment in the Colomadu Karanganyar sub-district. In this study, it begins with analyzing respondents' perceptions by conducting deep interviews. The results showed that 2 of these 15 people have Instagram but have not used IGTV optimally, while the remaining 13 people have Instagram social media and have promoted their products using IGTV. The factor that motivates these mothers to use Instagram social media is the factor of family needs. Those who initially worked but because of the pandemic lost their jobs then decided to open businesses to cover their needs and help the family economy. Of these 15 people decided to sell food products through Instagram social media. The ease of features that Instagram has, namely IGTV, can easily be used as a promotional medium. The obstacles they face are the lack of training to create attractive online promotional content, they still have few followers or followers.
\end{abstract}

\section{Keywords- Instagram, IGTV, Product Promotion, Termination of Employment}

Abstrak- Penelitian ini berjudul Optimalisasi IGTV Sebagai Sarana Promosi Produk Bagi Perempuan Korban Pemutusan Hubungan Kerja Pada Masa Pandemi Covid 19. Tujuan dari penelitian adalah perempuan yang terdampak secara ekonomi di masa pandemi covid 19 ini dapat memanfaatkan fitur-fitur media sosial seperti Instagram TV atau IGTV dalam memasarkan produk dengan jangkauan yang lebih luas. Ada hal yang menjadi fokus bahasan yaitu tentang perkembangan media sosial Instagram beserta fitur fitur yang ada di dalamnya, peranan media sosial Instagram sebagai sarana promosi produk, motivasi bisnis online para perempuan yang terdampak Covid 19, manfaat wirausaha bagi perempuan yang di PHK untuk meningkatkan perekonomian keluarga di masa pandemi sekarang ini, optimalisasi IGTV sebagai strategi promosi produk, kendalanya dalam optimalisasi IGTV. Metode yang digunakan dalam penelitian ini adalah deskriptif kualitatif, dimana pengumpulan data di lakukan melalui metode wawancara terhadap 15 orang ibu yang semula bekerja namun karena pandemi menjadi korban pemutusan hubungan kerja di lingkungan kecamatan Colomadu Karanganyar. Dalam penelitian ini dimulai dengan menganalisis persepsi responden dengan melakukan deep interview. Hasil penelitian menunjukkan bahwa dari 15 orang tersebut sebanyak 2 orang memiliki Instagram namun belum memanfaatkan IGTV secara optimal sedangkan sisanya sebanyak 13 orang memiliki media sosial Instagram dan sudah mempromosikan produknya menggunakan IGTV. Faktor yang menjadi motivasi ibu-ibu ini dalam memanfaatkan media sosial instagram adalah faktor kebutuhan keluarga . Mereka yang semula bekerja namun karena pandemi menjadi kehilangan pekerjaan kemudian memutuskan untuk membuka usaha guna menutupi kebutuhan dan membantu ekonomi keluarga. Dari 15 orang ini memut uskan menjual produk makanan melalui media sosial instagram. Kemudahan fitur yang dimiliki instagram yaitu IGTV dapat dengan mudah digunakan sebagai media promosi. Kendala yang mereka hadapi adalah minimnya pelatihan membuat content promosi online yang menarik, masih sedikit followers atau pengikut yang mereka miliki.

Kata Kunci- Instagram, IGTV, Promosi Produk, Pemutusan Hubungan Kerja

\section{PENDAHULUAN}

Perempuan memiliki peran besar dalam kemajuan perekonomian Indonesia. Hal ini dibuktikan di sektor Usaha Menengah, Kecil dan Mikro (UMKM) yang dijalankan oleh perempuan Indonesia memiliki kontribusi terhadap ekspor sebesar lebih dari 5 persen dan sekitar 64,5 persen. Fakta tersebut menandakan bahwa peran perempuan cukup besar terhadap perekonomian Indonesia [1] [2].

Kondisi pandemi Covid-19 memiliki dampak secara sosial dan ekonomi bagi perempuan. Berdasarkan data 16 April 2020 jumlah pekerja yang terkena Pemutusan Hubungan Kerja ( PHK) sebanyak 2.358 orang. Dari data tersebut sebanyak 762 orang 
atau hampir $30 \%$ adalah pekerja perempuan yang terkena PHK. Sedangkan pada Maret 2020 terdapat 32.000 pekerja migran pulang ke Tanah Air. Dari jumlah tersebut terdapat 70 persen pekerja migran perempuan. Pandemi virus corona membuat calon tenaga kerja perempuan lebih sulit mencari pekerjaan dibandingkan laki-laki. Ini lantaran sebagian besar tenaga kerja perempuan bekerja pada sektor-sektor yang mengharuskan bertemu dengan banyak orang atau orang-orang baru. Hal ini diperparah dengan minimnya tingkat pendidikan yang dimiliki oleh tenaga kerja perempuan sehingga banyak yang bekerja di sektor-sektor informal. Merintis bisnis online kini menjadi salah satu alternatif perempuan untuk mendapatkan pemasukan tambahan di tengah pandemi virus corona. Tercatat tren peningkatan permintaan melalui e-commerce maupun layanan antar online terus menunjukkan peningkatan [3].

Kehadiran sosial media di jaman modern seperti sekarang ini telah membawa banyak perubahan untuk dunia komunikasi [4]. Sosial media tidak hanya menjadi alat untuk berkomunikasi, tetapi juga menjadi sarana untuk mencari teman, berbagi foto bahkan sebagai sarana promosi bagi suatu bisnis toko online [5]. Media sosial juga adalah alat yang telah tersedia sebagai sarana untuk meningkatkan target penjualan dan bisa juga sebagai sarana untuk mengetahui jangkauan dari semua kegiatan promosi yang dilakukan [6]. Semua hal yang menguntungkan bisa saja terwujud, asalkan para pelaku usaha toko online bisa memanfaatkan media sosial dengan cara dan aturan yang tepat agar bisa menjalankan perannya sebagai tempat dan alat yang tepat untuk promosi dengan efektif [7].

Instagram saat ini digunakan hampir oleh 1 miliar orang di seluruh dunia. Tingginya jumlah pengguna Instagram menjadikan CEO Instagram mengeluarkan platform video pada Instagram yang diberi nama IGTV atau Instagram Television. Instagram TV merupakan platform video berbasis aplikasi. Baru diluncurkan oleh Instagram untuk pengembangan bisnis yang mereka lakukan. Konsep dalam IGTV serupa dengan Instastory, sama-sama ada dalam Instagram. Perbedaan antara keduanya ada dalam segi durasi waktu. Pada Instagram Story atau Instastory pengguna hanya diberikan lama waktu 30 detik untuk durasi video yang dapat di unggah. Sedangkan, pada Instagram Television durasi video bertambah cukup signifikan, antara 10 menit hingga 1 jam.
Platform video berdurasi lama dalam Instagram Television membuat Instagram Television menjadi platform video baru untuk mempromosikan produk dalam kebutuhan bisnis online. Ada beberapa alasan mengapa platform ini dinilai cukup efektif. Yang pertama adalah sebagai pengganti channel YouTube. Harus diakui bahwa untuk membangun sebuah channel YouTube perlu waktu yang lama. Sedangkan jika kita sudah memiliki banyak followers di Instagram, kita akan lebih mudah jika menghidupkan channel di IGTV. Keuntungan lainnya adalah karena belum terlalu banyak orang, terutama pebisnis, yang memanfaatkan IGTV sebagai sarana promosi di Instagram.

\section{KAJIAN PUSTAKA}

\section{Sejarah Instagram dan Fitur-Fiturnya}

Kevin Systrom adalah seorang programmer dan pengusaha internet. Setelah lulus dari Stanford University, ia bekerja di sejumlah tempat, salah satunya di Google sebagai manajer pemasaran produk. Tak lama kemudian, ia meninggalkan Google dan memilih untuk membangun perusahaan sendiri. Awalnya, ia menciptakan aplikasi bernama Burbn. Aplikasi ini memungkinkan pengguna untuk check-in ketika berada di tempat tertentu, membuat rencana, mendapat poin untuk bergaul dengan teman-teman, dan lain sebagainya.

Namun saat merombak Burbn, Kevin melihat kalau Facebook telah membuat aplikasi check-in seperti Foursquare. Akhirnya, bersama dengan Mike Krieger, Kevin menciptakan aplikasi lain berupa Instagram. Aplikasi berbagi foto ini memungkinkan penggunanya untuk mengambil foto, menerapkan filter tertentu, serta membagikannya ke sejumlah jejaring sosial. Sebulan setelah peluncuran, Instagram langsung meraup 1 juta pengguna. Setahun kemudian, Instagram berhasil mencapai lebih dari 10 juta pengguna.Tak disangka pada tahun 2012, Instagram sukses memikat perusahaan pesaingnya yaitu Facebook. Instagram akhirnya menerima tawaran akuisisi dari Facebook dengan nilai yang begitu fantastis, yaitu hampir USD 1 miliar.

\section{Fitur Instagram}

Penggunaan Instagram sekarang ini tidak hanya sebatas berbagi foto dan video saja, saat ini terdapat banyak fitur canggih yang disematkan pada media sosial terpopuler itu. Mulai dari Instagram 
Stories yang dapat digunakan untuk share video menarik dengan durasi 15 detik, hingga fitur Explore, Live dan IGTV untuk meraih popularitas. Fitur Explore pertama kali diperkenalkan pada Juni 2012. Dimana pengguna dapat melihat foto-foto dari akun tak dikenal, namun terbilang populer atau foto yang diambil di lokasi terdekat. Kemudian untuk fitur Live, pengguna dapat melakukan siaran langsung dan membuka QnA di fitur tersebut. Sementara untuk fitur IGTV, dapat digunakan bila kamu ingin mengunggah sebuah video dengan durasi hingga 10 menit.

\section{IGTV Sebagai Sarana Promosi Produk}

Instagram digunakan oleh hampir 1 miliar orang di seluruh dunia. Tingginya jumlah pengguna Instagram menjadikan CEO Instagram mengeluarkan platform video pada Instagram yang diberi nama IGTV atau Instagram Television. Instagram TV merupakan platform video berbasis aplikasi. Baru diluncurkan oleh Instagram untuk pengembangan bisnis yang mereka lakukan. Konsep dalam IGTV serupa dengan Instastory yaitu sama-sama ada dalam Instagram.

Perbedaan antara keduanya ada dalam segi durasi waktu. Pada Instagram Story atau Instastory pengguna hanya diberikan lama waktu 30 detik untuk durasi video yang dapat di unggah. Sedangkan, pada Instagram Television durasi video bertambah cukup signifikan, antara 10 menit hingga 1 jam. Platform video berdurasi lama dalam Instagram Television membuat Instagram Television menjadi platform video baru untuk mempromosikan produk dalam kebutuhan bisnis online. Berikut 3 strategi untuk memaksimalkan Instagram Television sebagai media promosi produk secara online:

\section{Pemilihan Audio dan Subtitle}

Strategi pertama adalah memilih audio dan subtitle yang tepat. Pemilihan audio dan subtitle sangat membantu dalam memaksimalkan fungsi dari IGTV. IGTV memberikan berbagai fitur yang dapat diakses, salah satunya adalah editing video sebelum diunggah pada channel yang Anda miliki. Pemilihan audio berguna untuk menayangkan video yang diunggah. Audio yang dimaksudkan adalah suara dalam video unggahan. Perhatikan bahwa kejernihan suara dan kualitas suara sangat berpengaruh pada menarik atau tidaknya iklan IGTV nantinya. Penggunaan suara jernih pada setiap video yang Anda buat, akan membuat video menjadi menarik bagi para pengguna IGTV.

Sedangkan subtitle membantu para pengguna IGTV memahami isi makna konsep video. Subtitle juga berfungsi untuk membantu penonton yang memiliki bahasa berbeda atau dalam artian, berasal dari negara lain. Subtitle juga berfungsi sebagai penjelas. Hal tersebut karena tidak semua orang menyalakan audio mereka saat menonton sebuah video.

\section{Input Link dan Hashtag}

Strategi kedua adalah menggunakan link dan hashtag. Link pada deskripsi IGTV merupakan link untuk beralih ke situs lain. Oleh karena itu, Anda dapat menggunakan deskripsi pada video untuk mengarahkan penonton beralih menuju website bisnis milik Anda. Kami menyarankan untuk membuat konten, atau beberapa bagian dari video, berisi ajakan untuk menekan link deskripsi untuk menuju website yang Anda miliki.

Selain link terdapat pula pemberian hashtag (tanda pagar) untuk mengenalkan video yang akan Anda iklankan pada IGTV. Pemberian hashstag pada IGTV berfungsi sama dengan hashtag pada Instagram pada umumnya. Peran hashtag dapat membantu mempromosikan video yang akan Anda upload agar dapat dilihat oleh publik.

\section{Review IGTV yang Anda Miliki}

Strategi ketiga untuk memaksimalkan peran dan fungsi IGTV adalah menggunakan review atau ulasan terhadap video. Review digunakan untuk memberikan penilaian atau ulasan terhadap konten. Hal tersebut berfungsi sebagai media promosi barang.

Masing-masing video tentu memiliki perhitungan dan karakteristik. Seperti halnya foto, merupakan citra yang melekat pada suatu barang atau produk tertentu. Dengan tujuan untuk mengenalkan keunggulan dari suatu produk agar bisa meningkatkan target jumlah barang terjual. Fungsi review di sini semacam ringkasan untuk memberitahu pengunjung bahwa channel IGTV bahwa bisnis Anda ini eksis. Sebab ciri dari sebuah bisnis yang tengah berkembang adalah eksistensi. Dan Anda pastinya ingin memberitahukan publik bahwa bisnis Anda tengah mengikuti tren di Instagram, apalagi bila sasarannya generasi millenial. Sudah pasti Anda selalu ingin mencoba hal baru untuk dijadikan bahan promosi. 


\section{Pengertian Pemutusan Hubungan Kerja}

Pemutusan Hubungan Kerja adalah pengakhiran hubungan kerja yang disebabkan karena suatu hal yang mengakibatkan berakhirnya hak dan kewajiban antara pekerja/buruh dan pengusaha/majikan.

\section{Kondisi Perempuan PHK Di Masa Pandemi}

COVID-19 tidak dipungkiri lagi telah berdampak hampir di semua sektor kehidupan masyarakat. Mengingat banyaknya sektor-sektor dalam roda perekonomian masyarakat yang harus tertunda, terhenti, mengalami perubahan besar mendadak, hingga dengan terpaksa harus berakhir. Perempuan kerap mengalami dampak sosial yang berlipat dari laki-laki di tengah kondisi isolasi di rumah akibat pandemi Covid-19 karena harus memegang beban ganda. dampak tersebut terutama dapat memengaruhi perempuan yang berkeluarga dan bekerja. Data Kementerian Ketenagakerjaan, hingga Juni 2020 sudah ada 5,23 juta pemutusan hubungan kerja (PHK), yang menurut Kementerian Pemberdayaan Perempuan dan Perlindungan Anak 30 persen di antaranya adalah perempuan.

\section{Penelitian Terdahulu}

Penelitian Dellia Mila Vernia (2017) Optimalisasi Media Sosial Sebagai Sarana Promosi Bisnis Online Bagi Ibu Rumah Tangga Untuk Meningkatkan Perekonomian Keluarga. Berdasarkan hasil penelitian menunjukkan bahwa ada penggunaan internet di Indonesia setiap tahunnya meningkat, dan ada 3 media sosial yang sering dikunjungi yaitu facebook, instagram dan youtube. Dalam pemasaran online, media sosial memiliki beberapa peranan penting diantaranya sebagai branding dan promosi yang efektif. Optimalisasi media sosial sebagai strategi bisnis ibu rumah tangga diantaranya yaitu konsisten untuk mengerjakan bisnis setiap harinya untuk mendapatkan hasil maksimal. Sedangkan kendala yang dihadapi para ibu rumah tangga dalam optimalisasi media sosial untuk bisnis online adalah minimnya pelatihan untuk penggunaan media sosial bagi para ibu rumah tangga.

Penelitian Ipah Latipah (2020) Pemberdayaan Perempuan Melalui Pemanfaatan Media Youtube Dalam Meningkatkan Keterampilan Wirausaha. Hasil penelitian menunjukan bahwa pemanfaatan media
YouTube yang digunakan dalam proses pemberdayaan perempuan dapat meningkatkan kreatifitas, minat dan motivasi para perempuan dalam kewirausahaan. Adapun kendala yang dihadapi yaitu minimnya fasilitas teknologi informasi dan komunikasi, kesibukan dalam mengurus rumah tangga, dan kurangnya rasa percaya diri ibu-ibu dalam memulai usaha.

\section{Kerangka Pikir Penelitian}

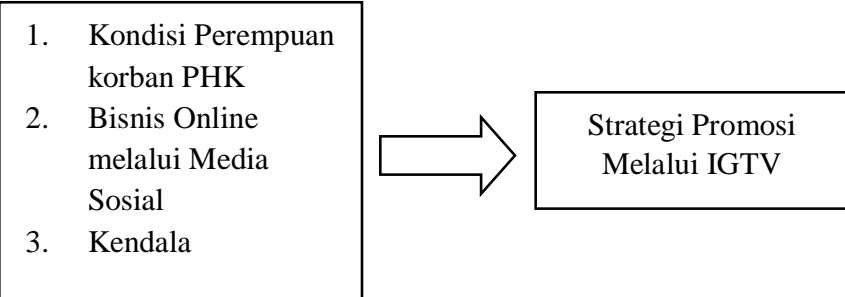

\section{Populasi dan Sampel}

\section{METODE PENELITIAN}

Populasi dalam penelitian ini adalah semua perempuan bekerja di lingkungan kecamatan colomadu Karanganyar yang terkena PHK. Sampel diambil sebanyak 15 orang perempuan bekerja yang terdampak pemutusan hubungan kerja. Pengambilan sampel melalui metode purposive sampling yaitu yang memiliki kriteria berjenis kelamin perempuan, sudah bekerja dan mengalami pemutusan hubungan kerja. Metode convience sampling digunakan untuk mendapatkan responden yang mudah ditemui dan memiliki waktu untuk di lakukan wawancara. Pengambilan data melalui metode wawancara dan literatur studi.

\section{Metode Penelitian}

Metode yang digunakan dalam penelitian ini adalah deskriptif kualitatif, dimana studi penelitian didasarkan pada wawancara dan literature study. Ada hal yang menjadi fokus bahasan yaitu tentang perkembangan media sosial, peranan media sosial sebagai upaya pemasaran bisnis online, motivasi bisnis para ibu rumah tangga, manfaat wirausaha bagi ibu rumah tangga untuk meningkatkan perekonomian keluarga, motivasi bisnis para ibu rumah tangga, optimalisasi media sosial sebagai strategi bisnis ibu rumah tangga, kendala ibu rumah tangga dalam optimalisasi media sosial untuk bisnis online. Peneliti menyiapkan pertanyaan-pertanyaan yang telah di siapkan dan responden menjawab secara terbuka. Literatur studi di perlukan guna menambah wawasan mengenai media sosial Instagram. Pengumpulan data 
dilakukan melalui wawancara terhadap responden. Peneliti sudah memiliki daftar pertanyaan yang di siapkan dan responden bisa menjawab dengan jawaban terbuka.

\section{HASIL DAN PEMBAHASAN}

Obyek penelitian ini adalah perempuan bekerja yang mengalami pemutusan kerja di Kecamatan Colomadu Kabupaten Karanganyar. Pengambilan data dilakukan dengan wawancara. Sampel yang digunakan dalam penelitian ini sebanyak 15 orang yang dapat dijelaskan sebagai berikut :

Tabel 1. Gambaran Umum Responden

\begin{tabular}{|c|c|c|c|c|}
\hline $\begin{array}{c}\text { Nama } \\
\text { Responden }\end{array}$ & Usia & $\begin{array}{l}\text { Tempat } \\
\text { Bekerja } \\
\text { Semula }\end{array}$ & $\begin{array}{c}\text { Lama } \\
\text { Bekerja }\end{array}$ & Alasan PHK \\
\hline Sri Suwito & 40 thn & Percetakan & 7 thn & $\begin{array}{l}\text { Tempat bekerja } \\
\text { tutup }\end{array}$ \\
\hline Kartini & 45 thn & Percetakan & 7 thn & $\begin{array}{c}\text { Tempat bekerja } \\
\text { tutup }\end{array}$ \\
\hline Nur Cahyo & 35 thn & Percetakan & 7 thn & $\begin{array}{l}\text { Tempat bekerja } \\
\text { tutup }\end{array}$ \\
\hline Ninik Bagyo & 44 thn & Percetakan & 7 thn & $\begin{array}{l}\text { Tempat bekerja } \\
\text { tutup }\end{array}$ \\
\hline Elisabet & 37 thn & Percetakan & 8 thn & $\begin{array}{l}\text { Tempat bekerja } \\
\text { tutup }\end{array}$ \\
\hline Derina & 45 thn & $\begin{array}{l}\text { Pabrik } \\
\text { Tekstil }\end{array}$ & 8 thn & Habis Kontrak \\
\hline Suratmi & 38 thn & $\begin{array}{l}\text { Pabrik } \\
\text { Teksil } \\
\end{array}$ & 8 thn & Habis Kontrak \\
\hline Kristiana & 42 thn & Percetakan & 8.5 thn & $\begin{array}{l}\text { Tempat bekerja } \\
\text { tutup }\end{array}$ \\
\hline Anita Rahayu & 32 thn & Hotel & 8.5 thn & Habis Kontrak \\
\hline Sukarsih & 35 thn & Hotel & 8.5 thn & Habis Kontrak \\
\hline Sundari & 32 thn & Hotel & 9 thn & Habis Kontrak \\
\hline Partini & 37 thn & Hotel & 9 thn & Habis Kontrak \\
\hline Theresia & 38 thn & Hotel & 10 thn & Habis Kontrak \\
\hline Susiana & 40 thn & $\begin{array}{c}\text { Pabrik } \\
\text { Makanan }\end{array}$ & 10 thn & $\begin{array}{l}\text { Tempat bekerja } \\
\text { tutup }\end{array}$ \\
\hline Suwarti & 41 thn & $\begin{array}{c}\text { Pabrik } \\
\text { Makanan }\end{array}$ & 10 thn & $\begin{array}{l}\text { Tempat bekerja } \\
\text { tutup }\end{array}$ \\
\hline
\end{tabular}

Sumber data diolah (2021)

Dari Tabel 1 dapat dijelaskan bahwa responden rata-rata berusia diatas 30 tahun dan dibawah 45 tahun. Semua responden masih dalam usia produktif. Dapat dijelaskan sebelum terdampak pemutusan hubungan kerja (PHK) responden bekerja di bidang Percetakan sebanyak 6 orang, Pabrik Tekstil sebanyak 2 orang, Pabrik Makanan sebanyak 2 orang, dan Hotel sebanyak 5 orang. Lama bekerja responden rata-rata 7 tahun hingga 10 tahun. Alasan responden mengalami pemutusan hubungan kerja sebagai berikut alasan PHK karena Tempat bekerja di tutup sebanyak 8 orang dan Habis Kontrak sebanyak 7 orang.

\section{Motivasi Bisnis Online di Kala Pandemi bagi Perempuan bekerja korban PHK}

Gelombang Pemutusan Hubungan Kerja (PHK) di tengah pandemi virus Corona, semakin terasa. Bagi kelimabelas responden yang terkena PHK efek Corona, mereka mencoba mencari cara untuk memenuhi kebutuhan hidup dengan berwirausaha. Ada dua cara untuk memulai usaha saat pandemi. Cara pertama yaitu bisnis online dan kedua, bisnis waralaba. Bisnis online meningkat tajam dikarenakan bisnis ini tidak memerlukan biaya yang besar, serta kemudahan dalam memasarkan produk, menjalankan usaha dan pasarnya luas. Berdasarkan hasil wawancara hal yang menjadi motivasi bisnis online di kala pandemi setelah mereka mengalami PHK adalah memperbaiki keadaaan ekonomi keluarga, memenuhi kebutuhan keluarga dan menjadi tulang punggung keluarga. Mereka memilih membuka usaha dengan pesangon yang ada agar dapat bertahan hidup di masa pandemi ini.

\section{Bidang Usaha Setelah PHK}

Berdasarkan hasil wawancara dengan responden setelah mereka mengalami PHK sebanyak 10 orang memutuskan untuk mencari pekerjaan lain dan memulai bisnis online menjual aneka produk , sedangkan sisanya sebanyak 5 orang memutuskan membuka usaha online saja karena juga harus mengurus keluarga. Bidang usaha yang mereka lakukan yaitu sebanyak 5 orang menjadi reseler produk fashion seperti pakaian dan aksesoris, sebanyak 4 orang menjual produk rumah tangga dan masker, sedangkan 6 orang lainnya menjual produk makanan. Media Sosial yang Digunakan

Media sosial yang digunakan responden adalah sebagai berikut ini sebanyak 8 orang menggunakan facebook dan instagram, sedangkan sisanya sebanyak 7 orang hanya menggunakan Instagram saja sebagai media sosialnya. Hal ini sebanyak 15 orang responden menggunakan Instagram. Media promosi yang mereka gunakan dalam mempromosikan produk mereka adalah instagram. Alasan mereka adalah faktor kemudahan, Instagram memiliki fitur gambar dan video sehingga lebih menarik, Instagram digunakan banyak orang. Pada mulanya mereka memanfaatkan media sosia Instagram hanya sebatas membagi kegiatan pribadi mereka. Namun sejak mereka mengalami PHK media sosial Instagram mereka manfaatkan sebagai media promosi. Sebagai langkah awal mereka mengajak teman dan saudara menjadi followers instagram mereka. Mereka juga belajar membuat konten yang menarik bagi itu dalam gambar maupun video. Fiturfitur yang dimiliki Instagram yaitu IG story, IGTV, IG 
live dan Instagram Shopping. Fitur yang di miliki Instagram yaitu IGTV mereka manfaakan dalam mempromosikan produk yang mereka jual. Durasi IGTV yang lama mereka gunakan untuk video testimoni produk, penjelasan lebih rinci tentang produk.

Respon followers dari video IGTV yang responden tayangkan mendapatkan respon yang positif. Karena video promosi yang melalui IGTV dianggap lebih jelas, menarik, lebih detail. Jika konsumen ingin bertanya mereka akan mengirimkan Direct Message kepada penjual.

Kendala yang responden hadapi adalah tidak adanya pelatihan mengenai media sosial bagi pemula dalam bisnis online. Rata-rata responden belajar secara otodidak dan mencoba-coba sendiri fitur-fitur yang ada di Instagram. Responden mengalami kesulitan dalam pembuatan konten video dan pembuatan foto yang menarik sehingga terkadang video yang mereka buat dianggap terlalu lama durasinya, informasi yang diberikan kurang jelas dan lain sebagainya. Pelatihan bagi penggiat bisnis online pemula sangat dibutuhkan.

\section{Kesimpulan}

\section{KESIMPULAN DAN SARAN}

Motivasi perempuan bekerja yang terdampak PHK dalam memulai bisnis online adalah adanya pemenuhan kebutuhan hidup, mempertahankan perekonomian keluarga, sebagaian dari mereka menjadi kepala keluarga. Membuka bisnis online mereka anggap mudah, tidak memerlukan modal besar dan memanfaatkan media sosial yang mereka pakai sehari-hariya. Sebelumnya media sosial mereka gunakan hanya untuk membagikan kegiatan mereka sehari-hari namun sekarang mereka memanfaaktkan media sosial Instagram guna membagikan serta mempromosikan produk jualan mereka. Fitur instagram yang mereka gunakan adalah IGTV karena responden menganggap mudah dan pegetahuan akan produk dapat di share atau dibagikan dalam bentuk video dan kompilasi foto-foto. Durasi IGTV yang lama bisa digunakan untuk menjelaskan produk secara detail serta di gunakan untuk tayangan testimoni konsumen terhadap produk. Kendala yang dihadapi responden dalam mengoptimalkan IGTV sebagai sarana promosi produk mereka adalah mereka belum mendapatkan pelatihan mengenai media sosial Instagram sehingga dalam pembuatan video dan pengambilan foto-foto masih terkesan seadanya. Konten video yang mereka buat belum menarik dan dianggap memiliki durasi yang lama.

\section{Saran}

Pendampingan bagi perempuan bekerja yang terdampak secara psikologis sangat dibutuhkan sehingga membuat mereka lebih bersemangat dan optimis dalam menjalani hidup serta memulai kembali berusaha baik untuk mendapatkan pekerjaan kembali ataupun membuka usaha. Pelatihan dalam membuat konten video dan pengambilan foto-foto guna mempromosikan produk jualan juga sangat diperlukan. Mereka bisa mengikuti pelatihan-pelatihan yang secara gratis seperti Webinar dari Gapura Digital, Webinar Women Will yang diadakan rumah kreatif yang secara rutin di lakukan.

\section{REFERENSI}

[1] P. H. Saputra, H. Bone, and I. Permatasari, "Peran Levers of Control Terhadap Hubungan Antara Perencanaan Strategis dan Kinerja UMKM," Bus. Innov. Entrep. J., vol. 1, no. 3, pp. 166-174, 2019, doi: 10.35899/biej.v1i3.69.

[2] N. A. Hamdani, S. Nugraha, and P. Purnamasari, "Conceptual Framework of Innovation Strategy in SMEs," BIEJ Bus. Innov. Entrep. J., vol. 2, no. 2, pp. 115-119, 2020.

[3] I. Permana, "Customer Switching Behavior dalam Membeli Batik dari UKM," Bus. Innov. Entrep. $J$. , vol. 1, no. 1, pp. 48-52, 2019, [Online]. Available: http://ejournals.fkwu.uniga.ac.id/index.php/BIEJ.

[4] R. Faozy, A. Ramdhani, and R. Nurhasan, "Analisis Faktor-Faktor yang Mendorong Kinerja UKM Pada Industri Wajit," BIEJ Bus. Innov. Entrep. J., vol. 2, no. 1, pp. 15-19, 2020, doi: https://doi.org/10.35899/biej.v2i1.75.

[5] D. Haryati and M. Ak, "Fenomena Cashless Society pada Generasi Milenial dalam Menghadapi Covid-19," vol. 3, no. 1, pp. 33-39, 2021.

[6] S. Hamid and P. Purnamasari, "Analysis Marketing Strategy of Coffee Luwak Cikole; A Case Study," vol. 2, no. 4, pp. 205-211, 2020.

[7] S. F. Nurfauziah, N. A. Hamdani, U. Garut, D. Sukagalih, and K. T. Kidul, "The Influence of Social Media Against Interest in Buying Kopilogi Products," vol. 3, no. 1, pp. 75-83, 2021.

[8] Dellia Mila Vernia, Optimalisasi Media Sosial Sebagai Sarana Promosi Bisnis Online Bagi Ibu Rumah Tangga Untuk Meningkatkan Perekonomian Keluarga, UTILITY: Jurnal Ilmiah Pendidikan dan Ekonomi Volume 1, No. 2, : Page 105-118, 2017 
[9] Ipah Latipah Pemberdayaan Perempuan Melalui Pemanfaatan Media Youtube Dalam Meningkatkan Keterampilan Wirasusaha, Jurna Comm-edu, Volume 3 Nomor 1, Mei 2020
[10] Irawan, Anugrahini dan Bambang Sudarsono; Analisa Faktor-faktor yang memotivasi Perempuan Berwirausaha Melalui Bisnis Online; Jurnal Distribusi Vol 6 No 2 September 2018 Hal 1 - 14 E-issn 2477-1767 